\title{
Pengembangan LKS Berbasis Kearifan Lokal di Malang Untuk Siswa Kelas IV SD
}

\author{
Arina Restian, Tyas Deviana, Yunia Nanda Eka Saputri \\ arina.poenya@gmail.com, tyasdeviana@gmail.com, yunianandaekasaputri@gmail.com \\ Pendidikan Guru Sekolah, FKIP, Universitas Muhammadiyah Malang
}

\begin{abstract}
This research aims to 1) develop a worksheet based on local wisdom in Malang for students in 4th grade, within subtheme 2: "The Beauty of My Country Cultural Diversity", 2) test the effectiveness of the worksheet. This study uses ADDIE model, there are 5 stages namely analysis, design, development, implementation, evaluation. The instrument was validated by material expert, instructional materials expert, and linguists. Then the revised worksheet was tested on the subject as a trial to find out the attractiveness and effectiveness. The validation result from the material expert was $90.67 \%$ in valid criteria, from the teaching material expert was $73.33 \%$ in criteria, and from the linguists were $93.33 \%$ in valid criteria. The attractiveness results $91.71 \%$ from students in interesting criteria and $85.71 \%$ from teachers. The effectiveness test results obtained $94.28 \%$ in effective criteria.
\end{abstract}

Keywords: Student Worksheet, Local Wisdom, Elementary School, The Beautiful Diversity Of My Country's Culture Sub-Theme

$\begin{array}{ccc}\text { Article Info } \\ \text { Received date: } 10 \text { Oktober } 2019 \quad \text { Revised date: } 10 \text { Januari } 2020 & \text { Accepted date: 22 Januari } 2020\end{array}$

\section{PENDAHULUAN}

Kurikulum 2013 berciri pembelajaran tematik, pembelajaran tematik merupakan pembelajaran yang bermakna dan berwawasan multikulural, hal tersebut dimaksudkan bahwa pembelajaran haruslah terdiri dari penguasaan bahan atau materi yang bermakna bagi kehidupan peserta didik selain itu haruslah berpikir yang matang dan bersikap dewasa sehingga dapat mandiri dalam memecahkan masalah dalam kehidupan peserta didik tersebut (Mamat S.B dkk dalam Prastowo, 2013). Namun perang urat syaraf sudah terjadi baik kalangan pemerhati, pengamat dan politisi serta praktisi dalam kerangka persepsi masing-masing. Salah satu contoh, ketika ada kebijakan penyempurnaan kurikulum pendidikan, seperti terbitnya Permendikbud No. 81A tahun 2013 tentang Implementasi Kurikulum 2013.

Kebijakan Kemendikbud RI ingin menerapkan Kurikulum 2013 (K-13) atau Kurtilas tingkat sekolah dasar hingga sekolah menengah. Pro-kontra (menyambut positif dan ada tanggapan negatif) muncul mengisi ruang publik, terkadang seolah-olah K-13 belum masanya atau waktunya diterapkan dengan banyak argumentais. Bahkan ada yang menilaisuatu yang mengkhawatir. Pentingnya K13 memiliki kreatifitas untuk memadu padankan dalam hal kreatifitas tematik terpadu, hal inilah yang membuat guru harus bersemangat berkarya, salah satunya adalah LKS.

Penerapan K-13 sejak pada tahun ajaran 2013/2014 secara terbatas, tidak pula ada kendala yang berarti, seperti di Kota Padang berdasarkan data Dinas Pendidikan setempat sedikitnya sampai pertengahan 2016, sudah tercatat sebanyak 23 sekolah pada tingkat SD yang melakukan penerapan K13.Menurut Durri Andrini (dalam Prastowo, 2013) LKS merupakan bahan ajar yang dikemas sedemikian rupa sehingga peserta didik dapat mempelajari materi ajar secara mandiri, pada LKS terdapat materi, ringkasan, dan tugas yang berkaitan dengan materi. Selain itu pada LKS peserta didik dapat menemukan arahan struktur untuk memahami materi yang diberikan (Ananda \& Fadhilaturrahmi, 2018).

Hasil wawancara observasi awal yang dilakukan pada tanggal 10 Desember 2018 dengan guru kelas IV C di SDN Kebonsari 2 Kota Malang, berdasarkan hasil obsevasi pada pembelajaran sudah menggunakan kurikulum 2013. Dalam wawancara disebutkan bahwa LKS yang ada sekarang kurang memperhatikan kegiatan-kegiatan peserta didik, selain itu LKS yang ada sekarang juga tidak mengaitkan adanya kearifan lokal yang ada pada daerahnya masing-masing. Sedangkan, hasil 
wawancara awal dengan beberapa peserta didik kelas IV diketahui bahwa peserta didik tidak mengetahui makanan yang berasal dari Malang. Saat ditanya mengenai tari yang berasal dari Malang ada sebagian yang menyebutkan tari yang berasal dari Malang dengan benar. Dan saat ditanya mengenai suku bangsa yang ada di Malang peserta didik tidak dapat menyebutkan suku bangsa tersebut. Sehingga peneliti perlu mengembangkan LKS yang sesuai dengan kearifan lokal lingkungan peserta didik. Peneliti mengembangkan LKS berbasis kearifan lokal Malang Subtema Indahnya Keberagaman Budaya Negriku.

\section{KAJIAN PUSTAKA}

Pembelajaran tematik merupakan pembelajaran dari berbagai kompetensi yang diintegrasikan ke berbagai muatan pembelajaran ke dalam tema dengan proses pembelajaran yang bermakna dan disesuaikan dengan perkembangan peserta didik (Akbar, 2016: 17). Dalam pembelajaran tematik di Sekolah Dasar pemerintah menyiapkan buku Guru dan Buku Siswa, selain itu guru juga dapat menambahkan refrensi buku yang akan digunakan dalam mengajar.

Bahan ajar ialah perangkat materi yang disusun sistematis baik tertulis dan tidak tertulis. Bahan ajar juga diperlukan guru untuk membantu dalam proses kegiatan pembelajaran yang ada dikelas, selain itu bahan jajar juga memiliki peran besar dalam memudahkan peserta didik untuk mengakses pengetahuan dan dapat memilki pengetahuan yang berbeda. Bahan ajar dapat dibedakan menjadi bahan ajar cetak dan non cetak (Airlanda, 2019).

Lembar Kegiatan Peserta Didik LKS merupakan salah satu bahan ajar yang non cetak. Lembar kegiatan peserta didik adalah bahan ajar cetak yang berisi lembaran-lembaran kegiatan yang dikerjakan oleh peserta didik dan terdapat langkah-langkah dalam menyelesaikannya sehingga dapat mencapai kompetensi yang diinginkan. Tugas yang diberikan dapat berupa materi ataupun praktik dan kegiatan tersebut dapat memberikan tanggung jawab kepada peserta didik dalam pembelajaran yang mereka pelajari.

Lampiran IV Permendikbud Nomor 81A tahun 2013 ditegaskan bahwa pembelajaran di sekolah tingkat dasar dikembangkan secara tematik, keterpaduan lintas mata pelajaran untuk mengembangkan sikap, keterampilan dan pengetahuan serta mengapresiasi kearifan lokal dalam pembelajaran. Dari penjelasan tersebut dapat ditarik kesimpulan bahwa pembelajaran di sekolah dasar dapat dikembangkan dengan mengabungkan kearifan lokal dalam pembelajaran yang dilakukan. Sejalan dengan hal tersebut menurut Daryanto, 2014 (dalam Shufa, 2018: 51) mengungkapkan bahwa melalui pendidikan, nilainilai luhur kebudayaan hendaknya dapat diperkenalkan kepada peserta didik serta dikembangkan sehingga peserta didik mampu menjadi pewaris yang bangga serta mampu mengembangkan budaya bangsa (Ananda \& Fadhilaturrahmi, 2018).

Kearifan lokal Malang yang akan diintegrasikan yaitu suku yang di Malang, tari daerah khas Malang, Bahasa dan makanan khas Malang. Hal ini telah disesuaikan dengan tema yang akan digunakan untuk mengembangkan LKS, hal ini sangat penting untuk memberikan sumbangsih pada pengembangan inovasi.

\section{METODE}

Model penelitian yang digunakan dalam penelitian ini yaitu Model ADDIE. Model ADDIE mempunyai lima tahapan yaitu, Analyze (analisis), Design (desain), Development (pengembangan), Implementation (implementasi) dan Evaluation (evaluasi). Tahap evaluasi pada model ADDIE meliputi evaluasi formatif dan evaluasi sumatif, evaluasi formatif dilakukan untuk mengumpulkan data pada setiap tahapan yang digunakan untuk menyempurnakan produk dan evaluasi sumatif digunakan untuk mengetahui pengaruh terhadap terhadap hasil belajar dan kualitas pembelajaran. 


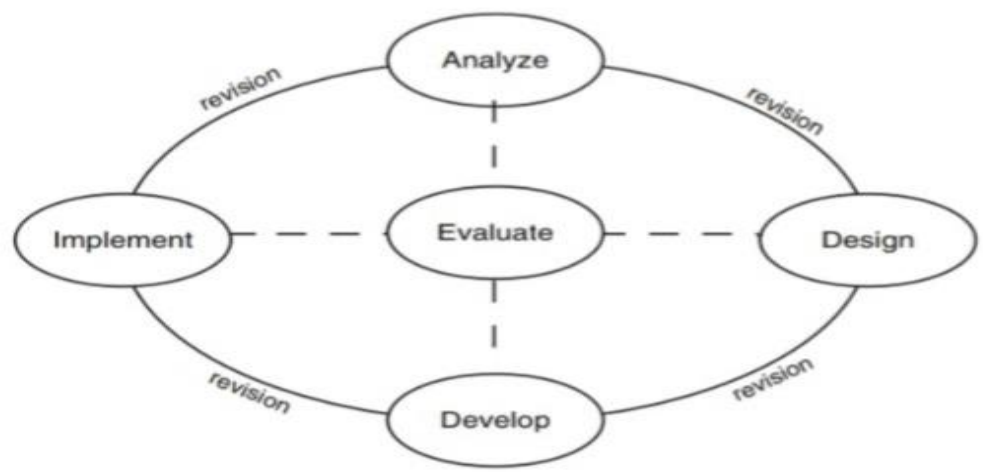

Gambar 1. Konsep ADDIE

Sumber: Branch (2019: 2)

Pengembangan yang akan dilakukan pada penellitian ini yaitu mengembangkan LKS yang berbasis kearifan lokal daerah. Kearifan lokal daerah yang akan digunakan pada pengembangan ini yaitu kearifan lokal Malang. Kearifan lokal Malang yang akan digunakan dalam pengembangan LKS ini yaitu tentang kebudayaan yang ada di Malang.

\section{HASIL DAN PEMBAHASAN}

\section{Hasil}

Hasil penelitian tentang pengembangan LKS berbasis kearifan lokal Malang Kelas IV Subtema Indahnya Keberagaman Budaya Negeriku di lakukan di SDN Kebonsari 2 Kota Malang. Berikut merupakan penjelasan dari hasil penelitian yang telah dikembangkan.

\section{Pengembangan LKS berbasis Kearifan Lokal Malang di Sekolah Dasar.}

a. Analyze (analisis)

Langkah awal kegiatan penelitian dan pengembangan yaitu melakukan analisis kebutuhan, analisis karakteristik peserta didik, analisis kurikulum, dan analisis lingkungan sekitar peserta didik. Hasil dari analisis kebutuhan yaitu di SDN Kebonsari 2 Kota Malang menggunakan LKS yang kurang memperhatikan kegiatan yang ada dan kurang mengkaitkan materi dengan kearifan lokal yang ada di Malang, sehingga diperlukan adanya LKS yang mengkaitkan materi dengan kearifan lokal Malang.

Analisis kurikulum yang diambil dari Kurikulum K13 tematik terpadu yang mengintregasikan berbagai bidang mapel/ Mata pelajaran. Digunakan untuk menganalisis antara KD dengan subtema, serta KD antar muatan pembelajaran. Sehingga dipilih Tema 7 Subtema 2 dengan keberagaman budaya yang ada di Malang sebagai pokok bahasannya. Analisis peserta didik mendapatkan hasil bahwa sosiobudaya yang tidak terlalu mencolok dan peserta didik berasal dari Malang, selain itu gaya belajar yang mereka sukai yaitu gaya belajar visual dan audio visual. Analisis lingkungan didapatkan hasil bahwa Malang memiliki keberagaman yang dapat diimplementasikan dalam pembelajaran yang ada di sekolah khususnya di SD.

b. Design (desain)

Tahap desain yaitu dengan merencang pengembangan LKS yang meliputi analisis kurikulum, menyusun peta kebutuhan, dan menentukan judul LKS. Selain itu juga membuat instrumen penelitian yang meliputi lembar angket validasi ahli materi, angket validasi bahan ajar, angket validasi bahasa, angket respon guru dan angket respon peserta didik.

c. Development (pengembangan)

Tahap pengembangan LKS berbasis kearifan lokal Malang yaitu memetakan KD dan indikator antar muatan pembelajaran, menentukan tema sentral dan pokok bahasan, menentukan alat penilaian, menyusun materi dan memperhatikan penulisan LKS berdasarkan struktur LKS. 
Pengembangan LKS Berbasis Kearifan Lokal di Malang Untuk Siswa Kelas IV SD

(Arina Restian, Tyas Deviana, Yunia Nanda Eka Saputri)

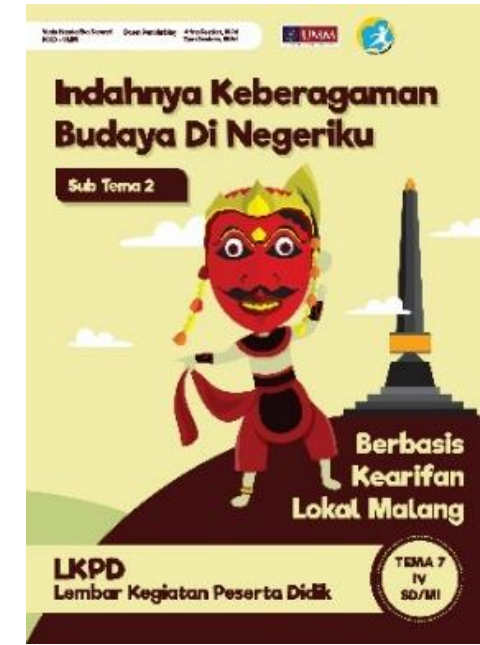

Gambar 2. Hasil Pengembangan Cover Depan LKS

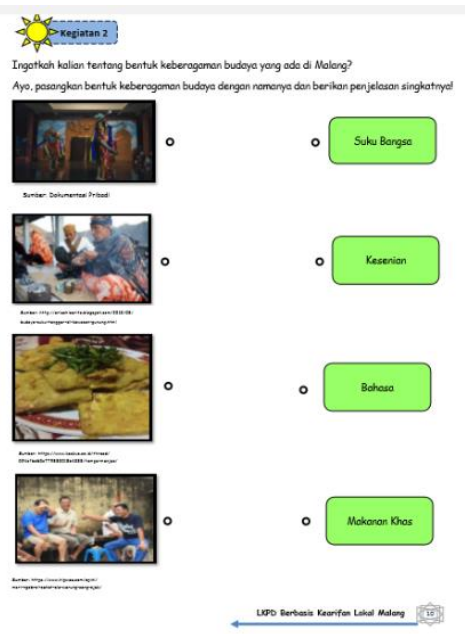

Gambar 4. Hasil Pengembangan Kegiatan Pembelajaran

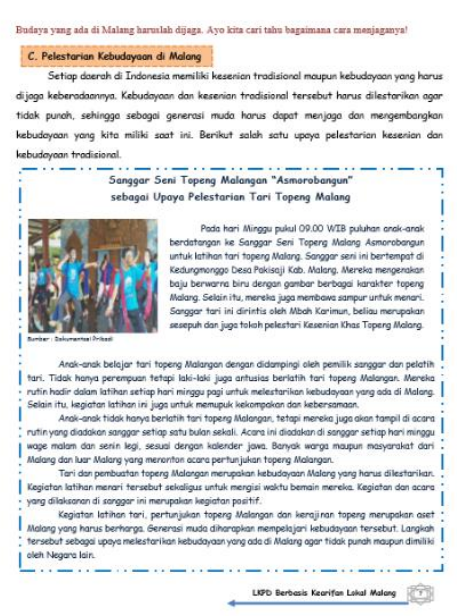

Gambar 3. Hasil Pengembangan Materi Pembelajaran

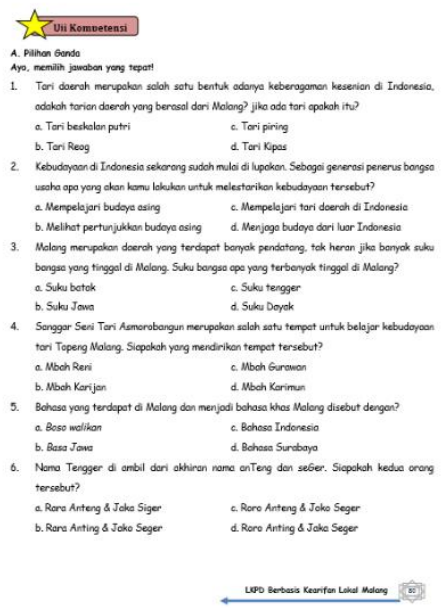

Gambar 5. Hasil Pengembangan Uji Kompetensi

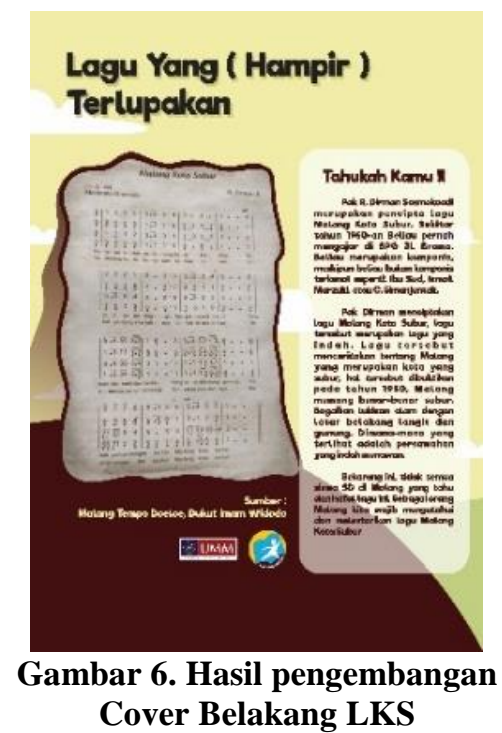

Setelah LKS dibuat langkah kepada para ahli. Validasi materi pembelajaran mendapatkan presentase $90,67 \%$ dari seluruh peserta didik, selanjutnya Ahli bahan ajar mendapatkan persentase 73,33\%. Ahli bahasa mendapatkan presentase 93,33\%. 


\section{d. Implementation (implementasi)}

Pada tahap implementasi mendapatkan hasil data nilai pengetahuan pembelajaran $1-6$, yang dijabarkan sebagai berikut:

Tabel 1. Distribusi Skor Rata-Rata Kelas Dan Persentase (\%) Ketuntasan Dari Kegiatan Pembelajaran

\begin{tabular}{ccc}
\hline Pembelajaran & Rata-rata Kelas & Persentase Ketuntasan \\
\hline Pembelajaran 1 & 79,47 & $72,72 \%$ \\
\hline Pembelajaran 2 & 81,97 & $78,78 \%$ \\
\hline Pembelajaran 3 & 81,95 & $77,14 \%$ \\
\hline Pembelajaran 4 & 84,71 & $94,28 \%$ \\
\hline Pembelajaran 5 & 84,41 & $97,14 \%$ \\
\hline Pembelajaran 6 & 86,42 & $100 \%$ \\
\hline
\end{tabular}

Dari hasil tersebut dapat dilihat bahwa pembelajaran dapat dikatakan berhasil karena memperoleh ketuntasan lebih dari $75 \%$ dari keseluruhan siswa-siswi.

Angket respon pengguna bertujuan untuk mengetahui kemenarikan dari LKS. Respon yang digunakan yaitu respon dari peserta didik dan guru, dimana dalam penilaiannya menggunakan penilaian ratting scale dengan skala 1 - 5 pada anget respon guru dan jawaban "Ya" "Tidak" untuk respon peserta didik. Hasil respon peserta didik mengasilkan presentase $91,71 \%$ dan hasil respon guru menghasilkan presentase 85,71\%. Dari hasil tersebut dapat dikatan LKS berbasis kearifan lokal Malang sangat menarik digunakan dalam kegiatan pembelajaran.

e. Evaluation (evaluasi)

Tahap evaluasi yang diguanakan yaitu evaluasi formatif dan sumatif. Evaluasi formatif digunakan untuk mengetahui evaluasi pada setiap tahap, mulai dari tahap analisis mengevaluasi hasil analisis kebutuhan, analisis kurikulum, analisis peserta didik dan analisis lingkungan sekitar. Tahap perencanaan mengevaluasi rancangan bahan ajar, tahap pengembangan mengevaluasi berdasarkan revisi dari validator, dan tahap implementasi mengevaluasi berdasarkan hasil implementasi dan angket respon. Evaluasi sumatif mengevaluasi semua tahapan ADDIE, mulai dari tahap analisis sampai dengan implemetasi (Sadri, 2012).

\section{Keefektifan LKS berbasis Kearifan Lokal Malang}

Hasil dari keefektifan LKS berbasis kearifan lokal Malang dari hasil pretest dan postest adalah sebagai berikut :

Tabel 2. Data Hasil Pretest Dan Posttes Berdasarkan Skor Persentase Ketuntasan

\begin{tabular}{ccc}
\hline Kegiatan & Hasil/Nilai & Ketuntasan \\
\hline Pretest & 69,37 & $34,28 \%$ \\
\hline Posttest & 80,11 & $94,28 \%$ \\
\hline
\end{tabular}

Dari hasil diatas dapat diketahui bahwa ketuntasan peserta didik keseluruhan hasilnya melebihi $75 \%$ yaitu dengan presentase $94,28 \%$ dari seluruh jumlah siswa- siswi. Sehingga LKS berbasis kearifan lokal Malang dikatakan efektif digunakan dalam pembelajaran di kelas IV pada tema 7 Subtema 2 Indahnya Keberagaman Budaya Negeriku dan dinyatakan betul- betul efektif dan anak- anak betulbetul memahami Lembar kerja peserta didik yang menyenangkan dan mereka belajar berbasis budaya khususnya Kota Malang (Watts, 2005).

\section{Pembahasan}

\section{Proses pengembangan LKS berbasis kearifan lokal Malang}

Proses pengembangan LKS dikembangkan sesuai dengan tahapan model ADDIE, dimulai dengan tahapan analisis. Tahap analisis menemukan permasalahan bahwa di SDN Kebonsari 2 Kota Malang membutuhkan LKS berbasis kearifan lokal Malang, hal tersebut dikarenakan menurut guru LKS yang ada kurang memperhatikan kearifan lokal dengan berisikan kegiatan-kegiatan yang bermakna. Hal tersebut sejalan pada lampiran Permendikbud No. 81A tahun 2013 bahwa pelajaran tersebut dijelaskan pada lampiran IV Permendikbud No. 81A tahun 2013 bahwa pembelajaran di tingkat dasar 
dikembangkan secara tematik, keterpaduan antar lintas muatan pembelajaran untuk mengembangkan sikap, keterampilan dan pengetahuan serta mengapresiasi kearifan lokal dalam pembelajaran (Mesquida \& Inocêncio, 2016).

Tahap perencanaan digunakan untuk menganalisis kurikulum tematik, penyusunan peta kebutuhan dan menentukan judul LKS. Setelah itu akan di validasi oleh beberapa ahli, yaitu ahli materi, ahli bahan ajar dan ahli bahasa. Selain itu juga membuat instrumen angket respon guru dan peserta didik. Sejalan dengan hal tersebut Trianto (2012: 143) mengemukakan bahwa dalam pelaksanaan pembelajaran tematik diperlukan beberapa persiapan yaitu persiaan jaring-jaring tema, pengembangan silabus dan penyusnan RPP (Oliva, 2014).

Tahap pengembangan dilakukan pemetaan KD dan indikator antar muatan pembelajaran, menentukan tema sentral dan pokok bahasan pada setiap pembelajaran, menentukan alat penilaian, menyusun materi dan struktur LKS. Kemudian akan divalidasi oleh para ahli, dengan memperoleh hasil validasi materi 90,67\%, ahli bahan ajar 73,33\% dan ahli bahasa 93,33\%. Dari hasil validasi tersebut dapat dikatakan LKS berbasis kearifan lokal Malang dapat digunakan dalam pembelajaran. Hal tersebut sependapat dengan Niven (dalam Sadun, dkk, 2016 : 83) bahwa menghasilkan produk yang berlangsung hendaknya memenuhi tiga kriteria yaitu valid, efektif dan praktis dengan didasarkan pada keesuaian dengan teori.

Tahap implementasi dapat dilihat bahwa peserta didik melakukan kegiatan sesuai dengan langkah yang ada pada LKS selain itu juga menyampaikan hasil dari kegiatan yang telah dilakukan, selain itu juga hasil belajar yang diperoleh peserta didik saat menggunakan LKS. Dari hasil tersebut didapatkan data bahwa banyak peserta didik yang memperoleh nilai di atas KKM yaitu diatas 75. Selain itu hasil angket respon peserta didik menunjukkan presentase 91,71 dan angket repon guru menunjukkan presentase $85,71 \%$. Dari hasil tersebut dapat dikatakan bahwa LKS berbasis kearifan lokal Malang menarik digunakan dalam pembelajaran. Sejalan dengan hal tersebut pembelajaran tematik tidak hanya memperhatikan kognitif saja, akan tetapi lebih menekankan pada keterlibatan peserta didk dalam pembelajaran (Sholikhah et al., 2019).

Tahap evaluasi dilakukan pada setiap tahapan mulai dari analisis sampai dengan implementasi. Dari data yang didapat mendapatkan hasil bahwa LKS berbasis kearifan lokal Malang dapat digunakan dan menarik dalam pembelajaran.

\section{Tingkat Keefektifan LKS Berbasis Kearifan Lokal Malang}

Keefektifan LKS berbasis kearifan lokal Malang dilihat dari hasil pretest dan posttest. Soal pretest diberikan sebelum peserta didik belajar menggunakan LKS dan soal posttest diberikan saat peserta didik belajar menggunakan LKS. Dari kegiatan pretest dan posttest didapatkan hasil rata-rata pretest 69,37 dan hasil rata-rata posttest 80,11. Sedangkan dilihat dari ketuntasan klasikal pada posttest mendapatkan 94,28\%. Sehingga dapat dikatakan bahwa LKS berbasis kearifan lokal Malang efektif digunakan dalam pembelajaran dikarenakan sudah mencapai ketuntasan klasikal diatas $75 \%$.

Keefektifan LKS berbasis kearifan lokal Malang didapat dari nilai posttes hal tersebut sejalan dengan pendapat Niven (dalam Sadun, dkk, 2016: 83) keefektifan produk didasarkan pada kemampuan produk dalam mencapai tujuan pembelajaran, tujuan pembelajaran dapat diketahui tercapai berdasarkan perolehan nilai dari evaluasi (Maryani \& Suparno, 2018).

\section{SIMPULAN}

Pengembangan LKS berbasis kearifan lokal Malang Kelas IV Subtema Indahnya Keberagaman Budaya Negriku di Sekolah Dasar, dikembangkan menggunakan model pengembangan ADDIE dan dirancang sesuai dengan analisis yang telah dilakukan. Harapannya dengan perkembangan Ilmu kedepan bisa memberikanSumbangsih pada pendidik di seluruh Jakarta. Berdasarkan hasil dari validasi para ahli LKS berbasis kearifan lokal Malang dikatakan dapat digunakan dalam pembelajaran dengan hasil presentase ahli materi 90,67\%, presentase ahli bahan ajar 73,33\% dan presentase ahli bahasa 93,33\%. Hasil belajar peserta didik mendapatkan presentase ketuntasan klasikal diatas $75 \%$. Dari hasil angket respon guru mendapatkan presentase $85,71 \%$ dan hasil angket respon peserta didik mendapatkan presentase $91,71 \%$, sehingga dapat dikatakan LKS berbasis kearifan lokal Malang menarik digunakan dalam pembelajaran. Berdasarkan pretest dan posttest diketahui bahwa LKS berbasis kearifan lokal 
Malang efektif digunakan dalam pembelajaran. Hal tersebut dilihat dari hasil pretest mendapatkan presentase ketuntasan 34,28\% dan pada posttest mendapatkan presentase ketuntasan 94,28\%.

\section{DAFTAR PUSTAKA}

Akbar, dkk. 2016. Implementasi Pembelajaran Tematik di Sekolah Dasar. Bandung: Jakarta Remaja Rosdakarya.

Airlanda, G. S. (2019). Identifikasi pemahaman sains mahasiswa PGSD UKSW tentang pola makan sehari-hari berbasis home science process skill. Scholaria: Jurnal Pendidikan Dan Kebudayaan, 9(1), 93-102.

Ananda, R., \& Fadhilaturrahmi, F. (2018). Analisis Kemampuan Guru Sekolah Dasar dalam Implementasi Pembelajaran Tematik di SD. Jurnal Basicedu, 2(2), 11-21.

Maryani, M., \& Suparno, S. (2018). EFEKTIVITAS MODEL PEMBELAJARAN KOOPERATIF TIPE JIGSAW DENGAN MINAT BELAJAR IPS SISWA SEKOLAH DASAR NEGERI MANGUNSARI 02 SALATIGA. Jurnal Pendidikan Sekolah Dasar (JPsd), 4(2), 272-284.

Mesquida, P., \& Inocêncio, K. C. M. (2016). Art and Education or Education through Art: Educating through Image. Creative Education, 7(9), 1214-1221.

Oliva, G. (2014). Education to Theatricality inside Secondary School, Art and Body. Creative Education, 5(19), 1758.

Sadri, N. W. (2012). Studi evaluasi implementasi pembelajaran tematik pada Sekolah Dasar Gugus I Denpasar Timur di Denpasar. Jurnal Penelitian Dan Evaluasi Pendidikan Indonesia, 1(2).

Sholikhah, F., Raharjo, T. J., \& Suhandini, P. (2020). The Effect of The STAD Learning Model Aided by Students Worksheet to Improve Critical Thinking Skills of Students. Journal of Primary Education, 9(1), 1-6.

Watts, R. (2005). Attitudes to making art in the primary school. International Journal of Art \& Design Education, 24(3), 243-253.

Branch, Robert Maribe. 2009. Instructional Design: The ADDIE Approach. New York, USA: Springer

Prastowo, Andi. 2013. Pengembangan Bahan Ajar Tematik. Jogjakarta: DIVA Press.

Prastowo, Andi. 2014. Pengembangan Bahan Ajar Tematik Tinjauan Teoritis dan Praktik. Jakarta: Kencana Prenadamedia Group.

Trianto. 2012. Desain Pengembangan Pembelajaran Tematik Bagi Anak Usia Dini TK/RA \& Anak Usia Kelas Awal SD/MI/. Jakarta: Kencana

Widodo, Dukut Imam .2015. Malang Tempo Doeloe. Surabaya: Dukut Publishing Surabaya. 